\title{
FEATURES OF FORCED QUARANTINE DISTANCE LEARNING
}

\author{
Oleksii Nalyvaiko \\ Ph.D. in Pedagogy, Associate Professor of Pedagogy Department, \\ V. N. Karazin Kharkiv National University, \\ 6 Svobody Sq., 61022 Kharkiv, Ukraine \\ nalyvaiko@karazin.ua, ORCID:0000-0002-7094-1047 \\ Anastasiia Vakulenko \\ Fourth-year student of Foreign Languages Department, \\ V. N. Karazin Kharkiv National University, \\ 4 Svobody Sq., 61022 Kharkiv, Ukraine \\ fullmetalanastasia@gmail.com, ORCID:0000-0001-7829-7236 \\ Uliya Zemlin \\ Fourth-year student of Foreign Languages Department, \\ V. N. Karazin Kharkiv National University, \\ 4 Svobody Sq., 61022 Kharkiv, Ukraine \\ mzemlin954@gmail.com, ORCID: 0000-0002-9800-2981
}

\begin{abstract}
The article deals with the study of the concept of distance education and its features. It reveals the investigation of the difference between various forms of distance learning, their positive and negative features as well. A number of rapid changes due to the process of modernization have recently influenced mostly all spheres of human lives, including the sphere of education. In its turn, the format of distance learning has gained more popularity by virtue of being more convenient and thus efficient. However, in Ukraine there is still prejudice about non-standard forms of education; the majority of school students is unaware of the possibility to be educated differently, though the existing distance learning schools offer different options. Unfortunately, the changes in education have also been affected by the outbreak of an epidemic because of COVID-19, which made the countries all around the world, including Ukraine, revise the education system and propose its new formats. Our work aims at differentiation of standard distance learning, which can also be called individual study, from forced quarantine distance learning, singling out their pros and cons and forming a conclusion about which form of education is the most effective. The article includes a poll, the results of which are depicted on diagrams, illustrating opinions of Ukrainian school students regarding this issue.

Keywords: distance education, distance learning, forced (distance) learning, individual study, quarantine (distance) learning.
\end{abstract}

\section{Наливайко Олексій}

кандидат педагогічних наук, доцент кафедри педагогіки,

Харківський національний університет імені В. Н. Каразіна, майдан Свободи 6, 61022, Харків, Україна, Вакуленко Анастасія

студентка 4 курсу факультету іноземних мов, Харківський національний університет імені В. Н. Каразіна, майдан Свободи 4, 61022, Харків, Україна,

\section{Землин Юлія}

студентка 4 курсу факультету іноземних мов,

Харківський національний університет В. Н. Каразіна, майдан Свободи 4, 61022, Харків, Україна,

\section{ОСОБЛИВОСТІ ВИМУШЕНОГО КАРАНТИННОГО ДИСТАНЦІЙНОГО НАВЧАННЯ}

Стаття присвячена дослідженню поняття “дистанційна освіта” та його облив остей. В ній продемонстровано вивчення та аналіз різниці між різними формами дистанційного навчання, їхні позитивні та негативні риси. Останнім часом стрімкі зміни, зумовлені процесом модернізації, впливають майже на всі сфери людського життя, включаючи й освітню. У свою чергу, формат дистанційного навчання набув і продовжує набувати більшої популярності завдяки тому, що є більш зручним i, отже, ефективним. Однак в Україні все ще існує певне упередження щодо нестандартних форм нав-

(c) O. Nalyvaiko, A. Vakulenko, Uliya Zemlin, 2020 
чання; більшість учнів шкіл не знаю про можливість отримати освіту по-іншому, хоча існуючі школи, що спеціалізуються на дистанційному навчанні, пропонують різні варіанти. На жаль, на зміни в освіті також уплинув спадах епідемії через COVID-19, який змусив країни у всьому світі, включаючи Україну, переглянути освітню систему та запропонувати її нові формати. Наша робота спрямована на розрізнення стандартного дистанційного навчання, яке також можна назвати "навчанням за індивідуальним планом", від “вимушеного карантинного дистанційного навчання", виокремлення їхніх позитивних та негативних рис і формування висновку про те, яка форма навчання $є$ більше ефективною. Стаття також включає опитування, результати якого подані зі схемами, що ілюструють думки українських школярів та батьків стосовно впровадження вимушеного дистанційного навчання.

Ключові слова: дистанційна освіта, дистанційне навчання, карантинне (дистанційне) навчання, примусове (дистанційне) навчання, здобувачі освіти, батьки.

\author{
Наливайко Алексей \\ кандидат педагогических наук, доцент кафедры педагогики, \\ Харьковский национальный университет имени В. Н. Каразина, площадь Свободы 6, 61022, Харьков, Украина, \\ Вакуленко Анастасия \\ студентка 4 курса факультета иностранных языков, \\ Харьковский национальный университет имени В. Н. Каразина, площадь Свободы 4, 61022, Харьков, Украина, \\ Землин Юлия \\ студентка 4 курса факультета иностранных языков, \\ Харьковский национальный университет имени В. Н. Каразина, площадь Свободы 4, 61022, Харьков, Украина, \\ ОСОБЕННОСТИ ВЫНУЖДЕННОГО КАРАНТИННОГО ДИСТАНЦИОННОГО ОБУЧЕНИЯ
}

Статья посвящена исследованию понятия «дистанционное образование» и его особенностей. В ней продемонстрировано изучение и анализ разницы между различными формами дистанционного обучения, их положительные и отрицательные черты. В последнее время стремительные изменения, обусловленные процессом модернизации, влияют почти на все сферы человеческой жизни, включая образовательную. В свою очередь, формат дистанционного обучения получил и продолжает получать большую популярность благодаря тому, что является более удобным и, следовательно, эффективным. Однако в Украине все еще существует определенное предубеждение относительно нестандартных форм обучения; большинство учеников школ не знаю о возможности получить образование по-другому, хотя существующие школы, специализирующихся на дистанционном обучении, предлагают различные варианты. К сожалению, на изменения в образовании также повлиял спадах эпидемии через COVID-19, который заставил страны во всем мире, включая Украину, посмотреть образовательную систему и предложить ее новые форматы. Наша работа направлена на различия стандартного дистанционного обучения, которое можно назвать «обучением по индивидуальному плану», от "вынужденного карантинного дистанционного обучения», выделение их положительных и отрицательных черт и формирования вывода о том, какая форма обучения является более эффективной. Статья также включает опрос, результаты которого представлены со схемами, иллюстрирующие мысли украинских школьников и родителей по внедрению вынужденного дистанционного обучения.

Ключевые слова: дистанционное образование, дистанционное обучение, карантинное (дистанционное) обучение, принудительное (дистанционное) обучение, соискатели образования, родители.

Introduction. The 21st century is a time of fundamental changes that affect absolutely all areas of our life, in particular, education. For modern Ukrainian students, secondary education has many traditional features that, over time, become less relevant and effective in the era of digitalization of the educational process. Society is moving towards to digitalization, which does not limit a person in space and time and allows using information in forms that are more acceptable for understanding, memorizing and applying in practice. One of such form is distance education. Distance education is defined as an innovative educational technology in which the leading role belongs to the independent educational activity of the learner, by using telecommunication technologies and minimizing classroom interaction between the subjects of educational activity [4].

Analysis of recent research and publications. It should be noted that distance education has become not only a great achievement for students, but also the subject of many studies. In particular, M. Karpenko [2], in his work "Development of distance learning as a response to modern challenges for Ukraine" noted that distance education is an important step towards informatization of society. It helps to increase the level of knowledge by avoiding time and space constraints, which is a 
significant advantage for students. However, considering the new format of education in the context of its introduction in Ukraine, M. Karpenko points to certain problematic areas that need to be reformed, including: improving the material and technical base; the introduction of adequate funding for a new field of education; improving the teaching process taking into account the specifics of distance learning and providing professionals who specialize in distance education.

Foreign authors also paid attention to the phenomenon of distance learning. In particular, J. Galusha, pointed out in her study "Barriers to Learning in Distance Education" [11] some obstacles to high-quality distance learning. In particular, she named the following: loss of interest in learning due to lack of personal contact with teachers and classmates, lack of support from teachers, feelings of isolation and inexperience with this way of learning, which leads to academic problems. The researcher also divided the inconveniences that can arise for students into categories: educational barriers that arise due to lack of quality teacher training for distance learning standards, and organizational barriers that occur due to poor infrastructure and lack of proper technological support [11].

T. Marusei \& T. Bilyk considered the issues of distance education from the standpoint of highlighting the positive features: interactivity of learning as a means of using the latest software to stimulate cooperation between students and teachers, the flexibility of student learning not to be tied to the classroom, individualization of training, which provides freedom of choice among the materials for study within a certain thematic block and the ability to have an individual study schedule [3].

Objective. The aim of our study is to compare classical distance education and compulsory distance education, which was proposed as an alternative to traditional education during the COVID-19 pandemic, as well as to highlight the advantages and disadvantages of the above forms of education.

Methods. The study was carried out in the period from 24.10.2020 to 31.10 .2020

The survey involved 68 respondents from different age groups (students and parents) who agreed to take the survey. The survey was conducted using Google Forms.

Below are attached questions as they were presented in the survey:

1. Do you know what distance learning means?

2. Are you satisfied with transition compulsory (quarantine) distance learning?
3. Would you like to have an individual plan of study?

4. Did you have/do you have comfortable conditions for distance learning (access to the Internet, personal workplace, etc.)?

5. Have the number of tasks for self-study and the amount of time you spend while studying increased? ers?

6. Do you get enough explanations from teach-

7. *Questions for parents* Did/do you have to explain the material to your child because of the $a b$ sence of teachers' explanations?

8. Do you have an access to the materials if you have missed several classes for some reason?

9. Is there a difference between distance learning lessons and full-time lessons at school (not taking into a consideration that they are held in Zoom or other applications/ programs)?

10. How do you think distance learning should be organized? (For example, leave online lessons or provide students with all the materials and allow them to study and consult with the teacher if there are questions, etc.).

Theoretical aspects of the research. The historical development of distance education will be valuable for our research. Appearing in the XVIII century (1700), distance education was presented in the form of an exchange of letters between students who studied shorthand and the teacher. The fact that they were all located in different parts of the United States did not become an obstacle to knowledge, but on the contrary served as a starting point for the implementation of distance education. This field of study was developed thanks to the followers of this idea, in particular, Isaac Pitman, who sent his lessons by mail to all comers, and soon found its reflection in the formation of distance education. Its first centers were the Institute of Distance Learning in Berlin, the first distance learning schools in the United States, where correspondence became a means of learning, and finally the University of Chicago, which in 1892 created the first distance learning program and became the first distance learning institution in the United States. The twentieth century brought new technologies that allowed the introduction of radio in the educational process, creating even separate educational channels, and with the advent of television in the 1950s - television courses. In 1969, a single Open University was founded in England, uniting all educational institutions that offered distance education. With the advent of the Internet, it has become possible to develop online courses, and in 1985, Southeastern University (Washing- 
ton, USA) offered accredited diplomas that could be obtained by taking such courses. In 1997, Blackboard introduced the first online distance learning platform, which laid the groundwork for the creation in 2011 of multifunctional Mass Open Online Courses (MOOCs) offering educational curricula to various universities [10; 12].

Taking into account the interest of many researchers in the topic of distance learning $[4 ; 11$; $12 ; 13]$, the question of relevance and need for this type of learning arises. The founder of the Ukrainian school of distance education "Dzherelo" emphasizes the following factors, in particular [6; 7]:

- The presence of children who are unable to study full-time due to illness, psychological or physical disabilities.

- The presence of hyperactive children who are involved in the cultural life of society and who participate in competitions, contests, Olympic Games and therefore cannot be constantly present in classes in full-time schools.

- The presence of "new age" children who belong to a new era because of their unwillingness to obey the rules of schools that exist according to outdated models of education.

- Presence of migrant children from other countries or regions of hostilities $[1 ; 6]$.

- This list can be added a few more main reasons why distance learning is becoming a priority:

- Parents' desire to increase the level of responsibility and self-organization of their children.

- Reluctance to waste time at school, where teachers cannot pay equal attention to all students, and they lose interest in the subject and the learning process in general.

- Parents' desire to free up more time for their children, which can be spent more productively, for example, engaged in self-development.

- Parents' desire for their children to learn the relevant information. As distance learning takes place through e-resources, the possibility of their constant updating is much higher in compeer with paper carriers.

- The opportunity for students to acquire skills and knowledge to independently apply them in practice, using modern technologies.

- The possibilities of this type of school [6]:

- Teaching children not only from all over Ukraine, but also from other countries. Today, the number of countries whose representatives are students of the "Dzherelo" distance school is 50.

- Education of children with special needs or children who do not have a comfortable form of full-time education, in particular, due to illness.

- Providing professionally oriented in various fields of education.

- Receiving secondary education in any place.

Due to the 2020 pandemic, Ukrainian students were forced to switch to distance learning. However, in our opinion, it is necessary to delimitate the concepts of "Distance Education" and "Forced Distance Education during the quarantine period 2020" - FDE2020.

In order to prove the difference between these two concepts and to understand which of the forms of education is more effective and convenient. We collected information on what the educational process looks like during "Distance Education" and "FDE2020" by reviewing the standards offered to distance learners and comparing them with the responses of students and parents of a regional school who have been forced to join distance learning through a pandemic [5].

The first major difference, which speaks of the need to delimitate between the two above concepts, is the fact that during distance learning parents and children discuss this step together before deciding on it, because they understand that the presence of the child at home and, in addition, the process of studying educational material poses certain needs, in particular, the availability of special equipment (computer, Internet); an appropriate atmosphere; places where the child can sit while studying the material and where no one will disturb him. During FDE2020, there was no time to discuss this step, as immediate measures had to be taken, so not all Ukrainian families were ready for this and could not organize the learning process properly. At a time when children were left without the direct help of teachers in explaining the material and needed parental help, there was complete chaos in some families, which did not allow students to concentrate on learning.

Another important factor that clarifies the concepts of "Distance Education" and "FDE2020" is the distribution of the workload among students. According to the rules of distance education, the student has the entire material base that he needs to pass the test, which certifies his ability to continue studying a particular subject. On the example of the Dzherelo distance education school and the Optima distance secondary school, we see that each of the students has his own personal digital study room, where the educational material is stored, and which he can study when it is convenient for him. Teacher consultation hours should be noted, which the student may attend as needed, or ask questions in 
private chat. In ordinary schools in the conditions of "FDE2020" such opportunities were not provided in general. Students had to spend hours in front of computer monitors to master the material, do their homework and send it for review. As a result, almost all parents interviewed had a negative response to "FDE2020". However, the main problem was the attempt of teachers to include the plan of full-time education in distance learning, which increased the physical and moral load of students and negatively affected their health.

It should also be noted that the Dzherelo distance school provides a universal learning platform, which also serves as a means of communication between the student and the teacher / tutor / classmates, the place of storage of educational material, testing. Each student has his own personal digital study room, the menu of which has such sections as: "Participants", "Teachers", "Students", "Channels", "Electives" and "Personal Chats". Going to the "Home Page" the student sees a list of subjects and, choosing any of them, immediately goes to the choice of a particular lesson, which, in turn, is divided into explanations of the theory in the form of video and test.

It is important that the list of subjects and topics that are available to each student of a distance education school who has his / her own office is freely available at any time. In addition, the student has the opportunity to use not only information on those subjects and topics that are provided by their level of education, but also to cover those topics that he considers interesting at the moment. In other words, a 9th grader has access to materials not only from 9 th grade, but from 1 st to 11 th grade, so at any time he has the opportunity to return to the topics of previous years, or vice versa - to look forward to the year if he needs it. A greater choice of educational material leads to a wider space of knowledge and, ultimately, the formation of a multifaceted personality.

In addition to the compulsory course, the student has access to the Materials section, which provides additional information on a variety of topics with relevant links. While studying the material, you can find instructions such as "To perform practical work, you need to download a contour map!" with a subsequent link to the download resource, which makes the learning process well-coordinated and convenient.

At that time, students who studied in the traditional form and were forced to resort to quarantine distance education did not have a universal digital resource where information was presented and stored. Online classes took place on various platforms, such as Zoom, Moodle, Google Classroom, using a large number of mobile applications, such as Viber, Whatsapp, Telegram, which brought a lot of inconvenience to students. In addition, the information of the lesson was not stored in video format, so the student who for some reason missed the lesson, was no longer able to listen to the teacher's explanation.

As for the assessment of knowledge, the system of control of students who studied in a distance school was built on the principle of modules, without passing such module the student was not able to proceed to the study of the following material. The implementation of any work that allows you to assess the level of knowledge is complex and contains "Conditions for completing the assignment", "Test part" and "Practical part", which gives students an understanding of what kind of assignment, is in front of him, and the opportunity to be comprehensively aware within this topic. If a student has problems in writing the final work and makes mistakes, he/she has the right to ask for help from the teacher, the list of advisory hours of which is also in the user's personal account, or use the forum to instantly maintain contact with the teacher.

However, according to the respondents, there are doubts about the existence of stable control in the secondary school during the quarantine period, because after sending homework, students did not always receive verified feedback, and therefore did not have the opportunity to assess and work on mistakes.

As mentioned above, students from distance school have not only teachers but also tutors who helped them to solve any issues, monitor students' progress and inform them about the counseling sessions. During FDE2020, this function was performed by parents.

Another difference between "Distance Education" and "FDE2020" is the presentation of educational material. It should be noted that in the school of distance education the educational material was presented in such a way that it is interesting to read and study.

This is indicated by the following elements: the presence of illustrations and audio fragments that give students an instant idea of the object of study; speech inversions and inserts, such as "Consolidating our knowledge!" or "Pay attention!", which create the effect of the teacher's presence and make the study of the material more energetic [9]. Regarding regular schools that have been FDE2020, it should be noted that not all teachers provided students with illustrative material in 
the form of presentations / video or audio files. However, respondents note the only plus that has made life easier for students was TV lessons. From April 6, 2020, teachers began tutoring lessons on $11 \mathrm{TV}$ channels, thus explaining the school program through screens. You could also watch them on YouTube. Classes were held Monday through Friday from 10 a.m. and covered grades 5-11.

Considering the above, we can conclude that the concept of "Distance Education" and "FDE2020" are radically different. If we talk about distance education in comparison with the forced quarantine distance education, then we can find a lot of positive features [6]:

- Combination of different forms of learning.

- Ongoing support of tutors.

- Round-the-clock access to the training site.

- Ability to work at an individual pace and return to the studied material at a favorable time.

- Opportunity to participate in cultural and educational activities for students.

- Freedom of action and convenience in learning, which has no territorial or age restrictions.

To this list should also be added factors such as the availability of a convenient system for processing material and communication; free access to a large amount of educational information; interesting presentation of the material, aimed at involving different types of memory (visual, auditory, logical), which is accompanied by tasks to check the mastered.

Results. This part of the paper reflects the results of a comparative analysis of 2 Ukrainian schools. One of them is the school of distance education "Dzherelo" in Kyiv, and a regional school, with the usual form of education which was switched to FDE2020. Respondents were asked nine multiplechoice questions and one open-ended question.

\section{8 answers}

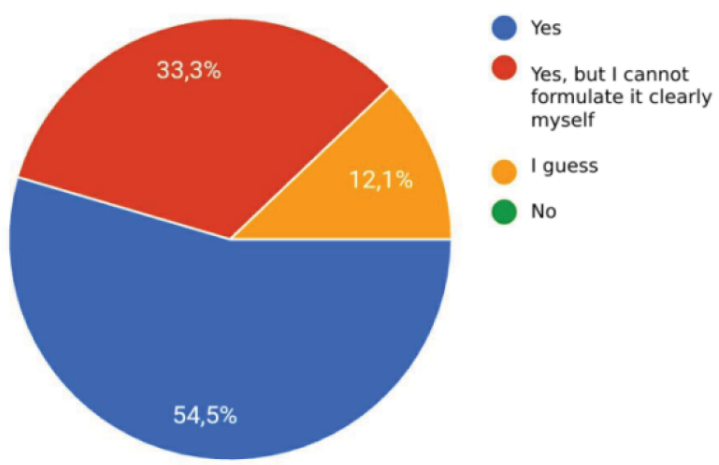

Fig.1. Question № 1. Do you know what distance learning means?
68 answers

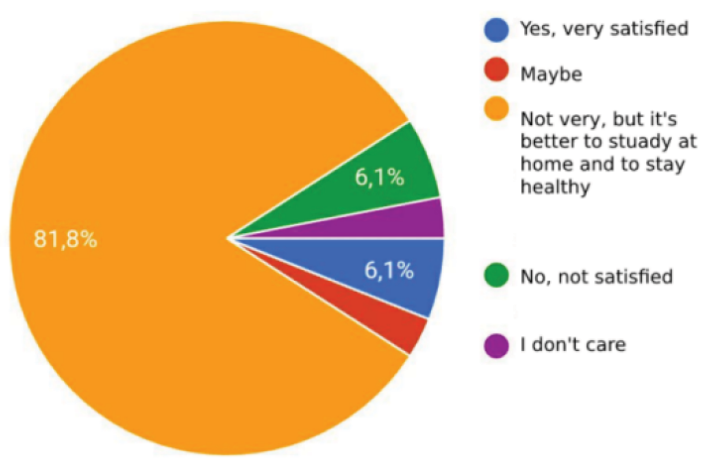

Fig.2. Question № 2. Are you satisfied with transition compulsory (quarantine) distance learning?

The answers to the first question showed that the majority of respondents $(54.5 \%)$ really know what distance learning means, or believe they do. $33.3 \%$ of students admitted that they roughly understand what this concept means, but do not clearly define it, and $12.1 \%$ only assume what can be meant by the term "distance education". Interestingly, none of the respondents chose the answer "No", which should mean that students are aware of how their learning process is built, but based only on the first question, we cannot be sure that students have the right understanding of this concept (Fig.1).

The above question shows that more than $80 \%$ of the respondents are not very satisfied with the need to switch to forced distance learning, but they understand that the measures are forced, therefore they are trying to get used to and adapt to an unusual format (Fig.2). The diagram also shows that an equal number of people chose the options "very satisfied" and "generally dissatisfied", which shows - depending on various factors, including learning conditions, students can be quite categorical in their attitude to quarantine distance learning. A very small number of students have either not yet decided on their attitude, or do not pay attention to this issue.

The answers to this question show that one third of the respondents want to change full-time education to study according to an individual plan, the other third - on the contrary. $33.3 \%$ of students said that they do not see the difference between such concepts as "individual learning" and "distance learning" and as a result cannot analyze which format would be best for them. Unfortunately, the lack of knowledge of this nature not only in students but also in their 
2020 Випуск/Issue 47

68 answers

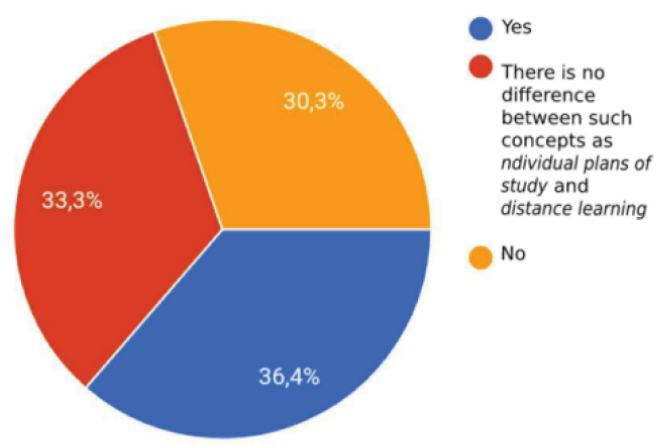

Fig.3. Question № 3.Would you like to have an individual plan of study?

parents leads to a lack of choice, and can affect the quality of knowledge, skills and the desire to learn in general (Fig.3).

This question outlines one of the main problems of quarantine distance learning: the lack of constant convenient conditions for distance learning, and its results clearly show that more than $60 \%$ of respondents do not always have a comfortable workplace, necessary equipment, Internet access, etc. Under such conditions, the quality of knowledge gained during quarantine training can quickly decline if students are not offered a single resource that would store all the information necessary for self-study, and revised the organization of training time. Compared to schools that have been forced to switch to distance learning, schools that position themselves as those that offer individual learning have the above features, which in turn contribute to more successful learning (Fig.4).

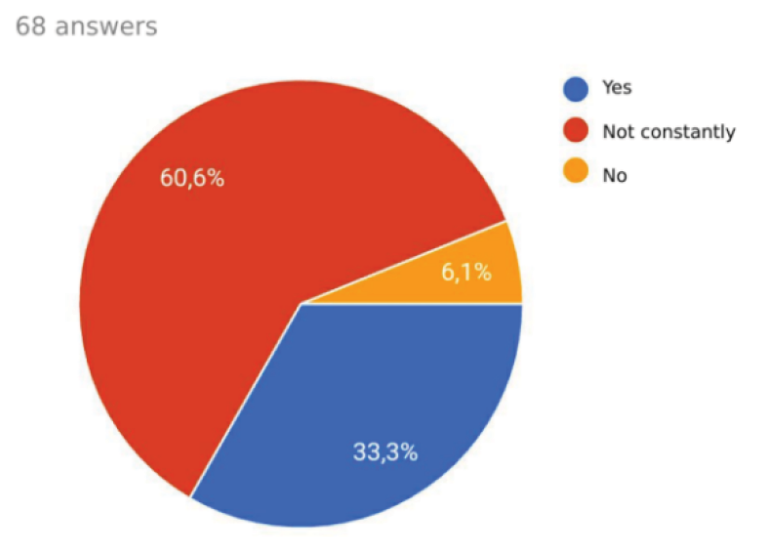

Fig.4. Question № 4.Did you have/do you have comfortable conditions for distance learning (access to the Internet, personal workplace, etc.)?

\section{8 answers}

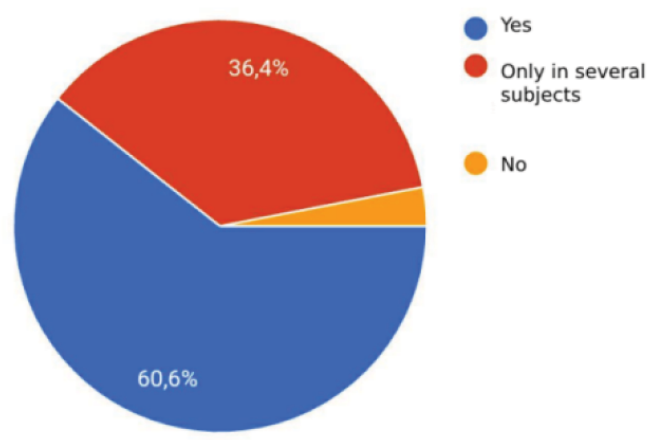

Fig.5. Question № 5. Have the number of tasks for self-study and the amount of time you spend while studying increased?

FDE2020 brought with it more material to study, so the time that students have / had to spend on tasks increased. Of course, the amount of homework depends on the individual subjects and teachers, as evidenced by $36.4 \%$ of the answers. Students from a school specializing in individual learning noted that the amount of material for selfstudy has not changed (Fig.5).

This question shows that more than $80 \%$ of respondents suffer from a lack of explanations on certain subjects. $12 \%$ are completely satisfied with the quantity and the number of information they receive from teachers. $6 \%$ note that with the FDE2020 format, there were not enough explanations (Fig.6).

In a separate question for parents, we noted that half of the respondents had / should additionally explain the material to the child, because there was lack of information in some subjects. The other half of the respondents were divided into parents who are lucky that children's

68 answers

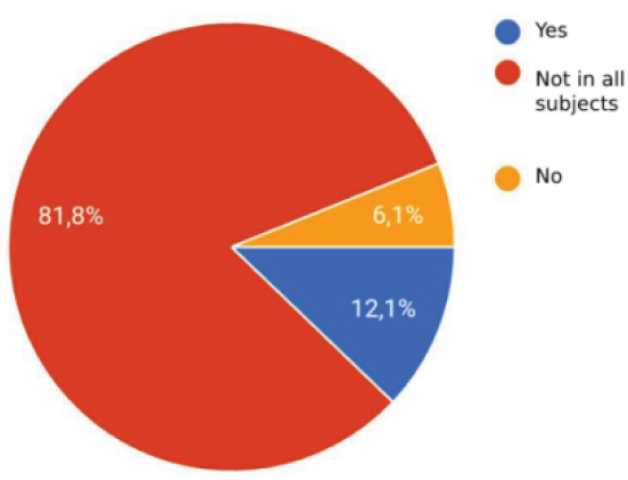

Fig.6. Question № 6. Do you get enough explanations from teachers? 
68 answers

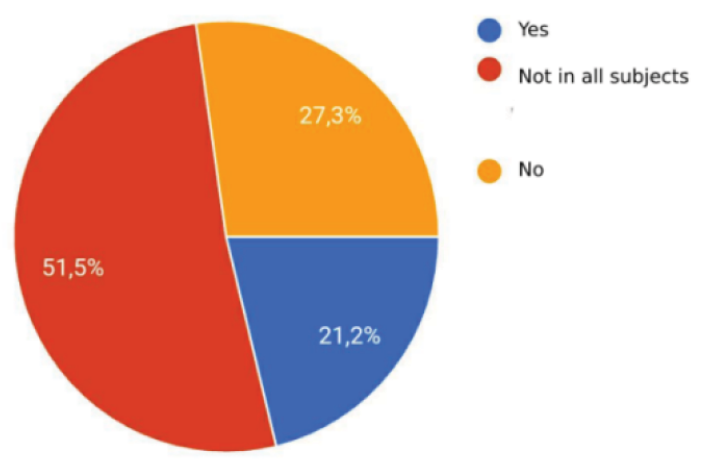

Fig.7. Question № 7. Did/do you have to explain the material to your child because of the absence of teachers' explanations?

teachers are responsible for their work even in unusual quarantine conditions, as well as parents who, on the contrary, are forced to take on the responsibilities of teachers and make up for the lack of knowledge with the child (Fig.7).

In the eighth question, $30.3 \%$ of students chose the option "No", admitting that they cannot get the necessary information from other sources, except during classes; almost half of the respondents stated that they have access to materials only in some subjects; only $20 \%$ of students indicated that they could always use all the necessary teaching materials (Fig.8).

Unfortunately, only $3 \%$ of respondents feel a significant difference, when the rest is divided into those who do not see the difference between classes before and during the pandemic, and those who have the opportunity to work with alternative forms of classes that should definitely be used when teaching material online (Fig.9).

The last question with options is whether students feel the difference between face-to-face classes and classes in Zoom, Skype and other applications or programs. It is also focused on the emergence of students' interest in checking whether they correctly understand the concept of "distance education", what functions they gain or lose during quarantine distance learning [8], and so on.

After analyzing the answers to the open-ended question, in which respondents (both students and parents) could share ideas about optimizing the learning process in the context of distance learning and the impression of online classes in general, we concluded that most students are dissatisfied with the quality of lessons: insufficient explanations from teachers and tasks processed in the online format, complete or partial lack of resources, where you can read more information
68 answers

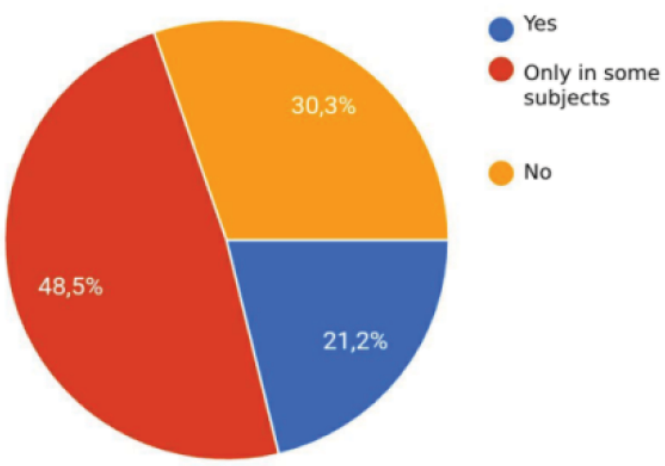

Fig.8. Question № 8. Do you have an access to the materials if you have missed several classes for some reason?

on the topic being studied, not considering the reasons that may be obstacles to student attendance, as well as volumes tasks for self-study, noting that the load has increased significantly compared to the amount of free time for rest. It should be noted that we also received a number of comments from parents of primary school students $(1-4 \mathrm{~K})$, in which the first described the transition to distance learning of primary school students is impractical, because children lose the opportunity to socialize and learn to work in team, spend a lot of time near the screens of gadgets or computers, do not realize more material, including due to incorrectly selected forms of training, and most importantly, do not understand how and why they learn, why they should listen to the teacher, looking at screen without being distracted. Junior students are not yet motivated and in quarantine conditions as a result of the lack of interesting

68 answers
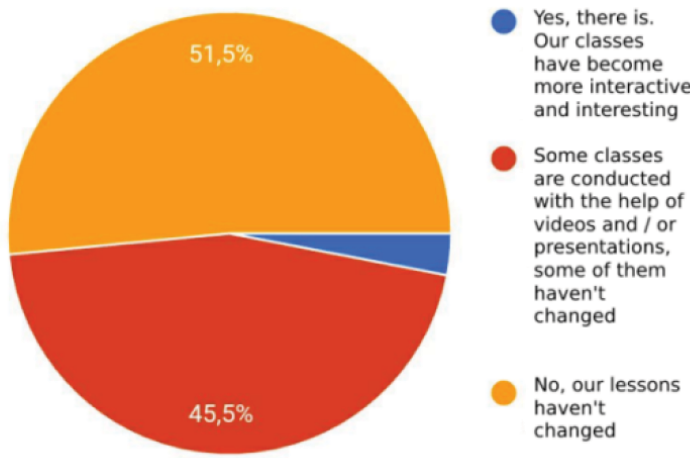

Fig.9. Question № 9. Is there a difference between distance learning lessons and full-time lessons at school (not taking into a consideration that they are held in Zoom or other applications/ programs)? 
2020 Випуск/ Issue 47

and receptive lessons, there is a risk that they will not be motivated in the future. Therefore, summarizing the above information, we can say that most respondents do not distinguish between normative distance education (according to an individual plan) and quarantine; students and their parents face the need to study the material on their own, with almost no complete recommended literature on useful references from teachers, as a result - the amount of free time decreases and productivity go low. Insufficient organization of the lesson and a poorly developed system of distance education in a pandemic leads to a deterioration in the educational indicators of the population.

Discussion and Conclusions. Therefore, having studied the educational process on the example of 2 schools, we were convinced that, compared to real distance schools, temporarily reformatted full-time educational institutions are not able to provide a high level of learning in critical conditions (for example, the situation during the 2020 pandemic), they have neither the appropriate teaching methods nor the material and technical base for this purpose. We need to notes that for the effective implementation of distance learning, teachers must have appropriate training that meets modern requirements for the organization of the educational process on the basis of mutual respect, understanding and use of innovative teaching methods and technologies. Such requirements include: the ability to create an atmosphere of mutual respect and mutual assistance, digital literacy, willingness to implement new approaches and methods in the educational process, the ability to agree on new forms of work (distance education), willingness to be creative in unusual situations.

In the future, we plan to continue to study the Ukrainian education system and its formats in order to improve and optimize the educational process and, as a result, increase education in the country.

\section{СПИСОК ВИКОРИСТАНИХ ДЖЕРЕЛ ТА ЛІТЕРАТУРИ:}

1. Дистанційна школа «Джерело» запрошує до 1-11 класів. URL: https://www.youtube.com/ watch?v=ysUUNxAdMkU (Дата звернення: 26.10.2020).

2. Карпенко М. Розвиток дистанційного навчання як відповідь на сучасні виклики для України. Стратегічні пріоритети. Нац. ін-т стратегічних досліджень. 2014. № 4 (33). С. 102-108.

3. Марусей Т., Білик, Т. Сучасні тенденції розвитку дистанційної освіти в Україні. Science, Research, Development. Pedagog. 2018. (8). 14-17.

4. Наливайко О. Дистанційне навчання: сутність та особливості. Педагогічний альманах. 2017. 36. С. 75-81.

5. Наливайко О., Вакуленко А., Землин Ю. Порівняльна характеристика класичного дистанційного навчання та його підвидів на прикладі викладання у закладах загальної середньої освіти. Всеукраїнська науково-методична конференція «Теорія і практика реалізації сучасних педагогічних методик та технологій в освіті» 19-20 листопада 2020 року Присвячена 170-річчю заснування кафедри педагогіки». Харків.

6. Офійний Ютуб канал. Дистанційна школа Джерело. Директор дистанційної школи “Джерело” про дистанційну освіту. URL: https://www.youtube.com/watch?v=AWGQYf9so5U (Дата звернення: 26.10.2020)

7. Офіційний сайт Джерело центр дистанційної освіти. Дистанційна школа №1 в Україні. URL: https://cdo. org.ua/ (Дата звернення: 15.11.2020)

8. Офіційний сайт МОН України. Відповіді на Топ-15 найпоширеніших запитань батьків про індивідуальну форму навчання в школі - роз'яснення MOH. URL: https://mon.gov.ua/ua/news/vidpovidi-na-top-15najposhirenishih-pitan-batkiv-pro-individualnu-formu-navchannya-v-shkoli-rozyasnennya-mon (Дата звернення: 08.10.2020)

9. Офіційний сайт. Центр освіти «ОПТIMA». Дистанційна загальноосвітня школа (1-11 класи) URL: https:// optima.school/ (Дата звернення: 26.10.2020)

10. Петькова Ю. История развития дистанционного образования. положительные и отрицательные стороны МООС. Успехи современного естествознания. 2015. № 3. 199-204.

11. Galusha, J. M. (1997). Barriers to learning in distance education. Interpersonal Computing and Technology: $A n$ Electronic Journal for the 21st Century, 5(3/4), 6-14.

12. Harting, K., \& Erthal, M. J. (2005). History of distance learning. Information technology, learning, and performance journal, 23(1), 35-44.

13. Valentine, D. (2002). Distance learning: Promises, problems, and possibilities. Online journal of distance learning administration, 5(3). URL: https://www.westga.edu/ distance/ojdla/fall53/valentine53.html (Дата звернення: 26.10.2020). 


\section{REFERENCES:}

1. Dy`stancijna shkola "Dzherelo" zaproshuye do 1-11 klasiv (2020) [Distance school "Dzherelo"invites to grades 1-11]. Retrieved from: https://cdo.org.ua/ (in Ukrainian).

2. Karpenko, M. (2014). Rozvy`tok dy`stancijnogo navchannya yak vidpovid` na suchasni vy 'kly `ky` dlya Ukrayiny` [Development of distance learning as a response to modern challenges for Ukraine]. Strategichni priory'tety: Nacionl'ny’y insy'tut strategichny’x doslidzhen - Strategic priorities. National Institute for Strategic Studies. № 4 (33). pp. 102-108 (in Ukrainian).

3. Marusei, T., \& Bilyk, T. (2018). Cuchasni tendenciyi rozvy`tku dy`stancijnoyi osvity`v Ukrayini [Current trends in the development of distance education in Ukraine]. Science, Research, Development. Educator. 8. 14-17 (in Ukrainian).

4. Nalyvaiko, O. (2017). Dystantsiine navchannia: sutnist ta osoblyvosti [Distance Learning: Essence and Features]. Pedahohichnyi almanakh - Pedagogical almanac, 36, 75-81 (in Ukrainian).

5. Nalyvayko O., Vakulenko A., Zemlin U. (2020, November 19-20). Porivnyal'na kharakterystyka klasychnoho dystantsiynoho navchannya ta yoho pidvydiv na prykladi vykladannya u zakladakh zahal'noyi seredn'oyi osvity [Comparative characteristics of classical distance learning and its subspecies on the example of teaching in general secondary education]. Paper presented at All-Ukrainian scientific-methodical conference "Theory and practice of implementation of modern pedagogical methods and technologies in education" Dedicated to the 170th anniversary of the Department of Pedagogy. Kharkiv. (in Ukrainian).

6. Official YouTube channel of Distance School "Dzherelo" (2020). dystantsiynoyi shkoly "Dzherelo" pro dystantsiynu osvitu [Director of the distance school "Dzherelo" on distance education]. Retrieved from: https://www. youtube.com/watch?v=AWGQYf9so5U (Access date: 26.10.2020) (in Ukrainian).

7. Official site Distance School “Dzherelo"(2020). Dystantsiyna shkola №1 v Ukrayini [Distance school №1 in Ukraine]. Retrieved from: https://cdo.org.ua/ (Access date: 15.11.2020) (in Ukrainian).

8. Official site of the Ministry of Education and Science of Ukraine (2020). Vidpovidi na Top-15 nayposhyrenishykh zapytan' bat'kiv pro indyvidual'nu formu navchannya v shkoli - roz'yasnennya MON. [The answers to the Top 15 most common questions of parents about the individual form of education at school - an explanation from the Ministry of Education and Science]. Retrieved from: https://mon.gov.ua/en/news/vidpovidi-na-top-15-najposhirenishih-pitan-batkiv-pro-individualnu-formu-navchannya-v-shkoli-rozyasnennya-mon (Access date: 08.10 .2020) (in Ukrainian).

9. Official site of the Education Center "OPTIMA"(2020). Dystantsiyna zahal'noosvitnya shkola (1-11 klasy) [Distance secondary school (K 1-11)]. Retrieved from: https://optima.school/ (Access date: 26.10.2020) (in Ukrainian).

10. Petkova Yu (2015). Istoriya razvitiya distantsionnogo obrazovaniya. polozhitel'nyye i otritsatel'nyye storony MOOC [History of the development of distance education. positive and negative aspects of MOOC]. Successes of modern natural science. No. 3. 199-204 (in Russian).

11. Galusha, J. M. (1997). Barriers to learning in distance education. Interpersonal Computing and Technology: An Electronic Journal for the 21st Century, 5(3/4), 6-14 (in English)

12. Harting, K., \& Erthal, M. J. (2005). History of distance learning. Information technology, learning, and performance journal, 23(1), 35-44 (in English).

13. Valentine, D. (2002). Distance learning: Promises, problems, and possibilities. Online journal of distance learning administration, 5(3). Retrieved from:https://www.westga.edu/ distance/ojdla/fall53/valentine53.html (Access date: 26.10.2020) (in English). 